interpreting some philosophic propositions. L. S. Kubie, in his paper on "Psychoanalysis and Scientific Method," bemoans the fact that psychoanalysis has been primarily a therapeutic tool, and recommends the use of psychoanalysis for pure research. The reviewer doubts that such a separation could ever take place. One of the most tolerant discussions was given by R. Demos in his paper "Psychoanalysis: Science and Philosophy." Incidentally, it is mellow, wise, humane and humorous as far as this reviewer is concerned.

What would have happened if philosophers such as J. Read and J. Richfield, who have had close contact with psychiatrists and psychoanalysts, had participated in this symposium?

\title{
BOOKS AND PAMPHLETS RECEIVED
}

Adler, Joshua. Philosophy of 7 udaism. New York: Philosophical Library, 1960. pp. 160. $\$ 3$.

Borgatta, Edgar F., David Fanshel, and Henry J. Meyer. Social Workers' Perceptions of Clients-A Study of the Caseload of a Social Agency. New York: Russell Sage Foundation, 1960. pp. 92. \$2.

Bugelski, B. R. An Introduction to the Principles of Psychology. New York: Rinehart, 1960. pp. 571. \$6. (With Instructor's Manual.)

Feifel, Herman, Ph.D. (Ed.). The Meaning of Death. New York: McGraw-Hill, Blakiston Division, 1959. pp. 351. $\$ 6.50$.

Glover, Edward. The Roots of Crime: Selected Papers on Psycho-Analysis, Vol. II. New York: International Universities Press, 1960. pp. 422. \$7.50.

Greenwood, David. The Nature of Science. New York: Philosophical Library, 1959. pp. 95. \$3.75.

Group for the Advancement of Psychiatry. Emotional Aspects of School Desegregation: A Report by Psychiatrists. (Report No. 37A.) An abbreviated and less technical version of Report No. 37. New York: GAP, 1960. pp. 48.50 cents.
Hock, Alfred, M.D. Reason and Genius: Studies in Their Origin. New York: Philosophical Library, 1960. pp. 138. \$3.75.

Kurtz, Russell H. (Ed.). Social Work Year Book 1960. New York: National Association of Social Workers, 1960. pp. 767. $\$ 8.50$.

Lichtenberg, Philip, Ph.D., Robert Kohrman, M.D., and Helen Macgregor, M.S.S. Motivation for Child Psychiatry Treatment. New York: Russell \& Russell, 1960. pp. 220. \$5.

May, Rollo (Ed.). Symbolism in Religion and Literature. New York: George Braziller, 1960. pp. 253. $\$ 5$.

Robison, Sophia M. Juvenile Delinquency: Its Nature and Control. New York: Holt, 1960. pp. 546. \$6.75.

Ross, Alan O., Ph.D. The Practice of Clinical Child Psychology. New York: Grune \& Stratton, 1959. pp. 275. \$5.75.

Sarason, Seymour B., et al. Anxiety in Elementary School Children. New York: Wiley, 1960. pp. 351. \$7.75.

Weinstein, Eugene A. The Self-Image of the Foster Child. New York: Russell Sage Foundation, 1960. pp. 80. \$2. 